\title{
Heat Transfer Rate of Sintered Zeolite Wick Heat Pipe
}

\author{
Luh Putu Ike Midiani ${ }^{1}$, I Nyoman Suprapta Winaya ${ }^{2 *}$, Wayan Nata Septiadi ${ }^{3}$, and Made Sucipta ${ }^{4}$ \\ ${ }^{1}$ Doctoral Study Program of Engineering Science, Faculty of Engineering, Udayana University \\ Kampus Sudirman, Denpasar-Bali, Indonesia. \\ ${ }^{1}$ Department of Mechanical Engineering, Bali State Polytechnic, \\ Badung, Bali, Indonesia \\ ${ }^{2,3,4}$ Study Program of Mechanical Engineering, Faculty of Engineering,Udayana University \\ Kampus Bukit Jimbaran, Badung-Bali, Indonesia \\ ike.midiani@gmail.com
}

\begin{abstract}
This paper discusses about heat transfer rate in heat pipe with sintered zeolite wick. The type of zeolite is natural zeolite and activated zeolite. Zeolite used in powder form divided into two grain size i.e. $100 \mu \mathrm{m}$ and $200 \mu \mathrm{m}$. Wick were made by sintering process. Calculation of the heat transfer rate for sintered zeolite heat pipe shows sintered zeolite activates heat pipe has the highest heat transfer rate.
\end{abstract}

Keywords: sintered zeolite, wick, heat pipe, heat transfer rate

\section{INTRODUCTION}

Wick is one of the most important parts of the heat pipe. Wick must circulate the working fluid inside heat pipe [1]. Commonly metal dominates the wick material such as copper, stainless steel or metal alloys [2-4]. Corrosion problems that occur because metals are easily oxidized will affect the performance of heat pipe, so natural material is an alternative. This natural material must be porous material. In this paper the natural material is zeolite.

Zeolite is natural rock with mineral and other compounds produced from hydrothermal processes. The unique properties of zeolite that are recommended as wick materials were adsorption-desorption capability, stable in thermal and chemical properties, porous material, and environmentally friendly [5-8]. Zeolites in Indonesia are found in volcanic regions.

The aim of this research is to study the thermal performance of heat pipes using sintered zeolite wick.

\section{EXPERIMENTAL}

In this study straight copper pipe used as heat pipe material with 9.6 outer diameter, $7.6 \mathrm{~mm}$ inner diameter and $550 \mathrm{~mm}$ length.

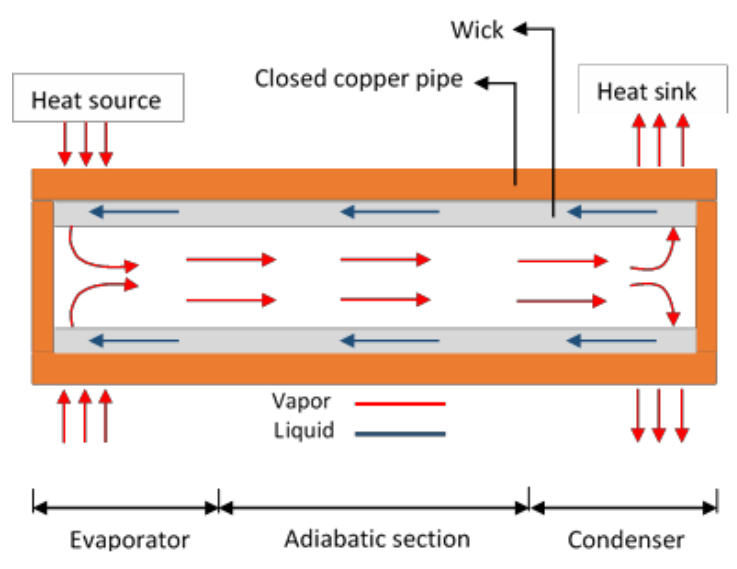

Fig 1. Schematic of sintered zeolite heat pipe

Wick heat pipe fabricated by sintering procees with $1 \mathrm{~mm}$ thicknes. Wick material in this study were natural zeolite and zeolite activation. The wick material in this study were natural zeolite and zeolite activation. Each type of material is distinguished by the powder granules size i.e. $100 \mu \mathrm{m}$ and $200 \mu \mathrm{m}$. Fig 1 shows the schematic of sintered zeolite heat pipe.

The thermal performance of sintered zeolite heat pipe was obtained by calculating the maximum heat transfer rate (Qmax). Maximum heat transfer rate depending on permeability $(\mathrm{K})$ and the working fluid 
mass flow rate $(\dot{\mathrm{m}})$ as summarized below :

$$
Q_{\max }=\dot{m}_{\max } . L
$$

where $\mathrm{L}$ is latent heat of the fluid. Working fluid mass flow rate $(\dot{m})$ equation is:

$$
\begin{gathered}
\dot{m}={ }^{\rho_{l} K A_{w}}\left\{{ }^{2 \sigma_{1}} \cos \theta-g l \quad \sin \emptyset\right\} \\
\mu_{l} l_{\text {eff }} r_{\text {eff }}
\end{gathered}
$$

where $\rho_{1}$ is the working fluid density, $\sigma_{1}$ is tension of the surface, $r_{\text {eff }}$ is radius pore effective, $\cos \theta$ is contact angle, $g$ is gravity, $l_{\text {eff }}$ is effective heat pipe length, sin $\phi$ is heat pipe position, $\mu_{1}$ is viscosity of the working fluid, and $A_{w}$ is the cross-sectional area of the wick. The equation of permeability $(\mathrm{K})$ is :

$$
\mathrm{K}=\frac{d p^{2} \cdot \varepsilon^{2}}{150(1-\varepsilon)^{2}}
$$

where $d_{p}$ is pore diameter and $\varepsilon$ is porosity.

\section{RESULTS}

The maximum heat transfer rate (Qmax) analyzed use existing data from previous studies [9]. The sintered zeolite heat pipe configurations shown in Fig. 2 with the measurements needed to obtain the mass flow rate of the fluid.

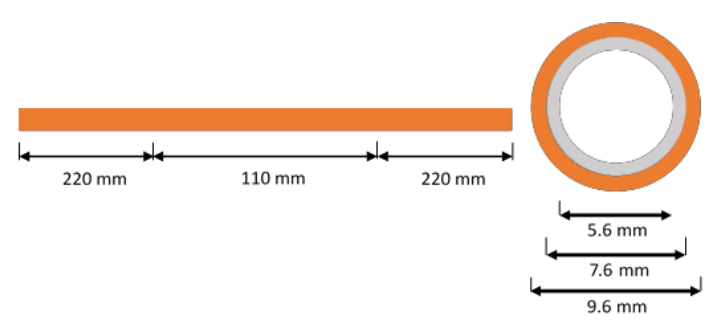

Fig 2. Design of sintered zeolite heat pipe

Maximum heat transfer rate calculation results which use equation (1), (2), (3) were shown in table 1.

\begin{tabular}{ccccr} 
Table 1 & & & \\
\hline No & Sample & $\mathbf{K}\left(\mathbf{m}^{\wedge} \mathbf{2}\right)$ & $\mathbf{m}(\mathbf{k g} / \mathbf{s})$ & $\begin{array}{r}\text { (kWatt) } \\
\text { • }\end{array}$ \\
\hline 1 & Z1 & $1.70 \mathrm{E}-15$ & 0.000185 & 0.42 \\
2 & Z2 & $7.86 \mathrm{E}-14$ & 0.005533 & 12.49 \\
3 & ZA1 & $5.97 \mathrm{E}-13$ & 0.121576 & 274.40 \\
4 & ZA2 & $1.28 \mathrm{E}-13$ & 0.003962 & 8.94 \\
\hline
\end{tabular}

The sample code $\mathrm{Z}$ is natural zeolite and $\mathrm{ZA}$ is zeolite activation. The number behind the sample code shows the powder grain size, which is 1 for grain size of $100 \mu \mathrm{m}$ and 2 for $200 \mu \mathrm{m}$. Fig. 3 shows the maximum heat transfer rate calculation result.

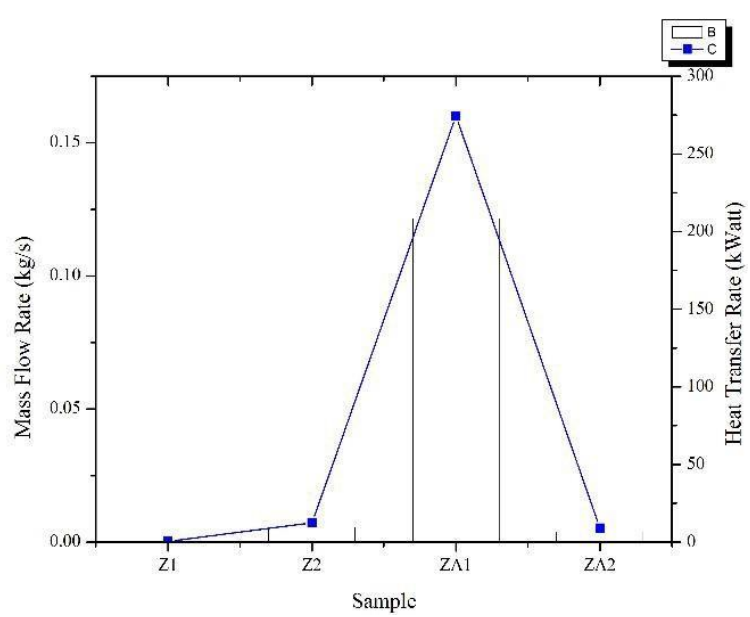

Fig 3. Design of sintered zeolite heat pipe

The highest maximum heat transfer rate is generated by a heat pipe with sintered zeolite activation grain size $100 \mu \mathrm{m}$, code sample ZA1. Maximum heat transfer rate of sintered zeolite heat pipe is $274.4 \mathrm{kWatt}$, while other heat pipes have maximum heat transfer rate below $100 \mathrm{kWatt}$.

\section{DISCUSION}

The maximum heat transfer rate was influenced by mass flow rate. The rate of mass flow for heat pipe with sintered zeolite grain size $100 \mu \mathrm{m}$ wick was obtained as $0.121576 \mathrm{~kg} / \mathrm{s}$, it was the highest mass flow rate. This high rate of mass flow was due to the permeability of the zeolite activation wick. Permeability of the zeolite activation wick was 5.97E-13, so that the working fluid can flow properly.

\section{CONCLUSIONS}

The heat pipe, maximum heat transfer rate influenced by the rate of mass flow of the working fluid. The rate of mass flow the working fluid will work optimally if supported by good permeability. In this study the sintered zeolite activation wick heat pipe with $100 \mu \mathrm{m}$ grain size obtain permeability $5.97 \mathrm{E}-13 \mathrm{~m}^{2}$ and the mass flow rate is $0.121576 \mathrm{~kg} / \mathrm{s}$, that produces the highest heat transfer rate among the other heat pipes. So that heat pipe with sintered zeolite activation wick with a grain size of $100 \mu \mathrm{m}$ can be recommended as a wick material.

\section{ACKNOWLEDGMENT}

Special thanks to the Directorate of Research and Community Service of Directorate General for Research and Development of the Ministry of Research, Technology and Higher Education In accordance with 
the Research Contract No. 415.49 / UN 14.4A / PL / 2017, dated March 30, 2017 through Research and Community Service Institute of Udayana University.

\section{REFERENCES}

[1] N. Putra, R. Saleh, W. N. Septiadi, A. Okta, and Z. Hamid, "Thermal performance of biomaterial wick loop heat pipes with waterbase $\mathrm{Al} 2 \mathrm{O} 3$ nanofluids," International Journal of Thermal Sciences, vol. 76, pp. 128136, 2014.

[2] K. De Kerpel, S. De Schampheleire, H. Steuperaert, P. De Jaeger, and M. De Paepe, "Experimental study of the effect of felt wick porosity on capillary-driven heat pipes," Applied Thermal Engineering, vol. 96, pp. 690-698, 2016.

[3] H.-M. Lee, M.-C. Tsai, H.-L. Chen, and H.-Y. $\mathrm{Li}$, "Stainless steel heat pipe fabrication, performance testing and modeling," Energy Procedia, vol. 105, pp. 4745-4750, 2017.

[4] J. Xu, L. Zhang, H. Xu, J. Zhong, and J. Xuan, "Experimental investigation and visual observation of loop heat pipes with two-layer composite wicks," International Journal of Heat and Mass Transfer, vol. 72, pp. 378-387, 2014.

[5] V. Orbukh, N. Lebedeva, S. Ozturk, and B. Salamov, "Electrical properties of the zeolite composites prepared by using zeolite and copper powders," Superlattices and Microstructures, vol. 54, pp. 16-25, 2013.

[6] O. Gencel, M. Sutcu, E. Erdogmus, V. Koc, V. V. Cay, and M. S. Gok, "Properties of bricks with waste ferrochromium slag and zeolite," Journal of cleaner production, vol. 59, pp. 111-119, 2013.

[7] S. K. Wahono, A. Kristiani, S. Tursiloadi, and H. Abimanyu, "Characterization and utilization of gunungkidul natural zeolite for bioethanol dehydration," Energy Procedia, vol. 47, pp. 263-267, 2014.

[8] E. Koohsaryan and M. Anbia, "Nanosized and hierarchical zeolites: A short review," Chinese Journal of Catalysis, vol. 37, pp. 447-467, 2016.

[9] L. P. I. Midiani, W. N. Septiadi, I. N. S. Winaya, M. Sucipta, and N. Putra, "Characterization of capillary pumping amount in novel sintered zeolites and hybrid zeolite- $\mathrm{Cu}$ for heat pipe applications," International Journal of Heat and Mass Transfer, vol. 145, p. 118759, 2019. 